\title{
PENGEMBANGAN PERANGKAT PEMBELAJARAN FISIKA MELALUI PENDEKATAN CTL UNTUK MEMINIMALISIR MISKONSEPSI FLUIDA DINAMIS
}

\author{
Susanti ${ }^{1)}$ \\ ${ }^{1)}$ Program Studi pendidikan Sains Pascasarjana Universitas Negeri Surabaya \\ e-mail: susan.fis@yahoo.co.id
}

\begin{abstract}
Abstrak: Penelitian ini bertujuan untuk memperoleh bukti dengan mengembangkan perangkat pembelajaran melalui pendekatan CTL agar terjadi penurunan miskonsepsi sesudah pembelajaran. Subyek penelitian berjumlah 75 siswa dari tiga kelas paralel yai tu kelas XII IPA1, XII IPA4, dan XII IPA5 di SMA Negeri 1 Surabaya. Penelitian dilakukan dengan metode CRI (Certainty of Response Index) untuk mengukur miskonsepsi siswa. Hasil penelitian menunjukkan miskonsepsi siswa pada materi fluida dinamis terjadi pada sebagian besar konsep di awal sebelum pemberian pembelajaran CTL. Persentase rata-rata miskonsepsi pada ketiga kelas replikasi, menunjukkan pada konsep persamaaan kontinuitas menyisakan miskonsepsi sebesar 26,4\%, pada konsep asas Bernoulli beserta penerapannya yaitu Teori Torricelli masih menyisakan miskonsepsi sebesar 25,3\%, dan pada konsep penerapan asas Bernoulli yang berikutnya yaitu pada pipa venturimeter masih menyisakan miskonsepsi sebesar 30,7\%, dan gaya angkat sayap pesawat terbang masih menyisakan masing-masing 10,7\%. Pada umumnya miskonsepsi siswa pada materi fluida dinamis mengalami penurunan meskipun ada beberapa siswa pada ketiga kelas replikasi mengalami kenaikan jumlah miskonsepi. Sehingga dapat disimpulkan bahwa pembelajaran fisika melalui pendekatan CTL dapat meminimalisir miskonsepsi siswa pada materi fluida dinamis.
\end{abstract}

Kata-kata Kunci: Fluida Dinamis, Miskonsepsi, Pendekatan CTL (Contextual Teaching and Learning)

\begin{abstract}
This Research purpose is to get the proof of the Development of teaching tool through CTL approach shows decrease of misconception after the learning. The amount of research subject contains 75 students from three classes, they are XII Science 1, XII Science 4, and XII Science 5 in SMA Negeri 1 Surabaya. The research has been done with CRI (Certainty of Response Index) method for measuring the Student's misconception. The research result shows the student's misconception of Dynamic fluid happened on the concept at the beginning of learning before the CTL approach. The average percentage of misconception on the three classes replication shows on the continuity equation shows $26.4 \%$, on the Bernoulli principal with the application of the Bernoulli, which is Torricelli theory shows $25.3 \%$ of misconception, and on the next concept of application of Bernoulli principal which is Venture meter shows $30.7 \%$ of misconception, and on the Aircraft's wing lifting shows $10.7 \%$ of misconception. On General Student Misconception happened on Dynamic fluid shows decrease level of misconception even though there are still few students on the three classes on the three replication classes shows increase of misconception level. The conclusion is Physic teaching and learning through CTL approach can minimize the misconception level for Students on Dynamic fluid subject.
\end{abstract}

Keywords: Dynamic fluid, Misconception, CTL approach (Contextual teaching and learning)

\section{PENDAHULUAN}

Fisika merupakan pelajaran yang bersifat abstrak yang menuntut kemampuan berpikir untuk memahaminya. Pada kenyataannya, siswa sering mengalami kesulitan dalam memahami berbagai konsep fisika. Pemahaman konsep fisika oleh peserta didik yang tidak sesuai dengan konsep fisika yang benar menurut ilmuwan, disebut miskonsepsi. Miskonsepsi dapat muncul pada diri siswa berasal dari pengalaman sehari- hari ketika berinteraksi dengan alamsekitarnya. Dengan pengalaman itu dibenak para siswa sudah terbentuk suatu intuisi dan ,teori siswa ${ }^{\text {ee }}$ mengenai peristiwa-peristiwa fisika tersebut yang sudah tentu intuisi dan teori yang terbentuk belum tentu benar.

Miskonsepsi pada siswa yang muncul secara terus menerus dapat mengganggu pembentukan konsepsi ilmiah. Pembelajaran yang tidak memperhatikan miskonsepsi menyebabkan siswa mengalami kesulitan belajar dan akhirnya akan bermuara pada hasil belajar fisika yang rendah. Miskonsepsi dapat terjadi pada siapa saja di setiap jenjang pendidikan, baik pada siswa sekolah dasar, sekolah menengah, mahasiswa, bahkan guru ataupun dosen.

Sehubungan dengan hal di atas, perlu dilakukan reorientasi dalam pembelajaran fisika. Pembelajaran fisika perlu dilakukan reorientasi yaitu beralihnya dari model pembelajaran konvensional menuju model pembelajaran yang berdasarkan atas paradigm konstruktivisme. Anak belajar lebih baik melalui kegiatan mengalami sendiri dalam lingkungan yang alamiah. Ada kecenderungan dewasa ini untuk kembali pada pemikiran bahwa anak akan belajar lebih baik jika lingkungan diciptakan secara alamiah. Belajar akan lebih bermakna jika 
anak mengalami sendiri apa yang dipelajarinya, bukan hanya sekedar mengetahui.

Pengajaran yang baik meliputi mengajarkan siswa bagaimana belajar, bagaimana mengingat, bagaimana berfikir, dan bagaimana memotivasi diri mereka sendiri (Nur, 2011). Menurut John Dewey (Carin, 1993) "children should "learning by doing" rather than be lectured to". Anak seharusnya belajar dengan melakukan daripada diceramahi. Sehingga siswa mengalami kesulitan dalam mengaplikasikan pengetahuan yang mereka peroleh dalam kehidupan nyata.

Pembelajaran CTL merupakan suatu pembelajaran yang membantu para siswa dengan cara yang tepat untuk mengaitkan makna pada pelajaran-pelajaran akademik mereka. Ketika para siswa menemukan makna di dalam pelajaran mereka, maka mereka akan belajar dan ingat apa yang mereka pelajari. Pendekatan ini pada dasarnya menekankan pentingnya siswa membangun sendiri pengetahuan mereka lewat keterlibatan aktif proses belajar-mengajar.

Menurut Johnson (2006) bahwa CTL membuat siswa mampu menghubungkan isi dari subjek-subjek akademik dengan konteks kehidupan keseharian mereka untuk menemukan makna. Pendekatan ini pada dasarnya menekankan pentingnya siswa membangun sendiri pengetahuan mereka lewat keterlibatan aktif proses belajar-mengajar. Proses belajar-mengajar lebih diwarnai student centered daripada teacher centered. Sebagian besar waktu proses belajar-mengajar berlangsung dengan berbasis pada aktivitas siswa.

Pendekatan pengajaran dan pembelajaran kontekstual atau Contextual Teaching and Learning (CTL) biasa disebut dengan pembelajaran kontekstual. Definisi CTL menurut Blancard (Trianto, 2008), Contextual Teaching and Learning (CTL) merupakan suatu konsepsi yang membantu guru menghubungkan konten materi ajar dengan situasi dunia nyata dan memotivasi siswa untuk membuat hubungan antara pengetahuan dan penerapannya ke dalam kehidupan mereka sebagai anggota masyarakat. Sesuai dengan karakteristiknya pendekatan CTL melibatkan tujuh komponen utama pembelajaran efektif, yaitu; konstruktivisme (Constructivism), inkuiri (inquiry), bertanya (Questioning), masyarakat belajar (Learning Community), pemodelan (Modeling), refleksi (Reflection), penilaian sebenarnya (Authentic Assesment).

Berdasarkan pemahaman tersebut, teori pembelajaran kontektual berfokus pada multiaspek lingkungan diantaranya ruang kelas, laboratorium fisika, maupun out door (luar kelas). Sehingga mendorong para guru untuk memilih dan mendesain lingkungan belajar yang dimungkinkan untuk mengaitkan berbagai bentuk pengalaman sosial, budaya fisik, dan psikologi dalam mencapai hasil belajar. Di dalam suatu lingkungan yang demikian, siswa dapat menemukan hubungan yang sangat bermakna antara ide-ide abstrak dan penerapan praktis di dalam konteks dunia nyata.

Konsep-konsep fisika umumnya diajarkan secara hirarkhis dari konsep yang mudah ke sukar, dari konsep yang sederhana ke kompleks, sehingga jika konsep yang mudah dan sederhana saja sudah mengalami miskonsepsi, maka lebih lanjut pemahaman konsep-konsep fisika yang sukar dan kompleks, siswa akan semakin kesulitan dan mengalami kesalahan pemahaman konsep secara berlarut-larut.

Meskipun miskonsepsi yang terjadi pada siswa sulit diperbaiki dan selalu meninggalkanv"sisa" yang berpengaruh pada pemahaman konsep fisika yang lain, tetapi seorang guru diharapkan tetap berusaha untuk membantu siswa untuk keluar dari miskonsepsi yang terjadi. Langkah awal yang digunakan untuk memperbaiki miskonsepsi adalah mengidentifikasi miskonsepsi yang terjadi pada siswa. Banyak cara yang dapat digunakan untuk mengidentifikasi miskonsepsi siswa, diantaranya yaitu tes piihan ganda dengan alasan terbuka dengan menyertakan Certainty of Response Index (CRI). Certainty of Response Index (CRI) merupakan teknik untuk mengukur miskonsepsi sesorang dengan cara mengukur tingkat keyakinan atau kepastian sesorang dalam menjawab setiap pertanyaan yang diberikan. Metode CRI dikembangkan oleh Saleem Hasan.

Tujuan penelitian ini adalah: mendeskripsikan kelayakan perangkat pembelajaran fisika melalui pendekatan CTL untuk meminimalisir miskonsepsi fluida dinamis yang dikembangkan, meliputi: 1) Mendeskripsikan hasil validitas perangkat pembelajaran fisika yang dikembangkan menggunakan pendekatan CTL. 2) Mendeskripsikan keterlaksanaan RPP selama proses pembelajaran yang menggunakan perangkat pembelajaran fisika yang dikembangkan melalui pendekatan CTL. 3) Mendeskripsikan aktivitas siswa dalam KBM dengan menggunakan pengembangan perangkat pembelajaran fisika melalui pendekatan CTL. 4) Mendeskripsikan respon siswa terhadap KBM dengan menggunakan pengembangan perangkat pembelajaran fisika melalui pendekatan CTL untuk meminimalisir miskonsepsi fluida dinamis. 5) Mendeskripsikan penurunan miskonsepsi siswa setelah pembelajaran melalui pendekatan CTL. 6) Mendeskripsikan kendala-kendala yang ditemukan dalam penelitian di lapangan dan bagaimana cara untuk mengatasinya.

\section{METODE PENELITIAN}

Penelitian ini dilaksanakan di SMA Negeri 1 Surabaya pada bulan Juli - Agutus 2013 sebanyak tiga kali 
pertemuan terdiri dari tiga kelas paralel yaitu kelas XII IPA1, XII IPA4, dan XII IPA5 pada semester gasal tahun pelajaran 2013/2014 yang diawali dengan uji awal (pretest) dan diakhiri dengan uji akhir (posttest). Subjek penelitian adalah perangkat pembelajaran fisika dengan menggunakan pendekatan CTL pada materi fluida dinamis.

Penelitian dilaksanakan melalui tiga tahap, yaitu pengembangan perangkat dengan model Kemp, validasi perangkat, dan ujicoba lapangan dengan rancangan one group pretest-posttest design.

Desain ujicoba dirumuskan seperti di bawah ini:

\section{O1 X 02}

Keterangan:

$\mathrm{O} 1=\mathrm{Uji}$ awal (pretest), untuk mengetahui materi sebelum perlakuan

$\mathrm{O} 2=\mathrm{Uji}$ akhir (posttest), untuk mengetahui penguasaan materi sesudah perlakuan

$\mathrm{X}=$ Perlakuan pembelajaran dengan pendekatan CTL

Sebelum perlakuan siswa diberikan pretest dan setelah perlakuan diberikan posttest. Teknik yang digunakan untuk pengumpulan data dalam penelitian ini, diantaranya adalah: 1) teknik dokumentasi, untuk mendapatkan data-data mengenai kevalidan perangkat pembelajaran yang dikembangkan, dengan mendokumentasikan lembar chek list para validator sebagai dasar untuk merevisi perangkat pembelajaran yang dikembangkan, 2) teknik observasi, observasi bertujuan untuk mengumpulkan data penelitian tentang kemampuan guru mengelola pembelajaran/ keterlaksanaan RPP yang dilakukan dua orang pengamat, aktivitas siswa saat pembelajaran berlangsung dan kendala yang dihadapi selama pelaksanaan pembelajaran dilaksanakan, 3) teknik tes, tes yang digunakan dalam penelitian ini adalah tes diagnostik miskonsepsi untuk mengetahui kelemahan siswa dalam memahami konsep materi fluida dinamis. 4) teknik angket, pemberian angket digunakan untuk mengumpulkan informasi tentang respon siswa terhadap kegiatan pembelajaran dengan cara memberi penilaian dan menjawab sesuai dengan kriteria yang disediakan.

\section{HASIL DAN PEMBAHASAN}

Validasi perangkat pembelajaran oleh pakar dilakukan untuk mengetahui perangkat tersebut baik/tidak digunakan dalam proses pembelajaran. Perangkat pembelajaran yang divalidasi meliputi; RPP, buku ajar siswa, lembar kerja siswa (LKS), kisi-kisi soal tes diagnostik miskonsepsi. Hasil validasi RPP diperoleh rata-rata penilaian dengan rentang skor 3 sampai 4, sehingga dapat disimpulkan bahwa RPP adalah baik dengan sedikit revisi dan layak digunakan untuk pembelajaran. Hasil validasi buku ajar siswa menunjukkan kelayakan isi diperoleh skor penilaian rata- rata 3,74; bahasa penulisan buku diperoleh skor penilaian rata-rata 3,47; serta penyajian diperoleh skor penilaian rata-rata 3,62. Hasil validasi LKS meliputi ketiga komponen yaitu Format diperoleh skor rata-rata 3,84; Isi diperoleh skor rata-rata 3,79; serta bahasa diperoleh skor rata-rata 3,86. Dari ketiga komponen tersebut menunjukkan bahwa ketiganya termasuk dalam kategori baik. Hasil validasi soal tes diagnostik miskonsepsi dapat dikategorikan bahwa soal tes cukup valid, dapat dipahami sehingga dapat digunakan meskipun dengan sedikit revisi.

Keterlaksanaan penggunaan RPP pada ujicoba II diamati oleh 2 orang pengamat. Dari penelitian yang dilakukan menunjukkan bahwa rata-rata kemampuan guru (peneliti) dalam melaksanakan pembelajaran yang meliputi pendahuluan, kegiatan inti dan penutup berkategori baik. Kemampuan guru dalam mengelola pembelajaran tidak terlepas dari keikutsertaan atau keaktifan siswa dalam mengikuti pembelajaran. Kegiatan pembelajaran yang dilaksanakan disesuaikan dengan langkah-langkah perencanaan yang dibuat peneliti sesuai dengan RPP. Hal ini membuat siswa sangat berantusias dalam mengikuti kegiatan pembelajaran tersebut sehingga pembelajaran berpusat pada siswa dapat tercapai, meskipun tidak terlepas dari bimbingan guru. Skor antusiasme siswa pada ketiga kelas replikasi dalam mengikuti kegiatan pembelajaran dengan pendekatan CTL yang diperoleh rata-rata sebesar 3,7 dengan kategori baik.

Aktivitas siswa yang paling dominan pada pembelajaran dengan pendekatan CTL pada ketiga kelas replikasi adalah melakukan pengamatan, demonstrasi atau percobaan sebesar 13,9\%; bekerjasama dalam kelompok serta mendiskusikan hasil pengamatan masingmasing sebesar 13,2\%; sedangkan diskusi, tanyajawab antar siswa atau guru sebesar 13,1\%. Masih ditemukan perilaku yang tidak relevan sebesar $0,2 \%$. Serta pula dilakukan perhitungan rata-rata reliabilitas aktivitas siswa pada ujicoba II masing-masing pada kelas replikasi I sebesar 91.3\%, kelas replikasi II sebesar 89,0\%, dan kelas replikasi III sebesar 89,5\%. Aktivitas-aktivitas siswa tersebut yang dominan mencerminkan bahwa pembelajaran berpusat pada siswa dan pembelajaran pembelajaran berlangsung aktif. Bruner mengungkapkan bahwa pembelajaran penemuan menekankan pada pengalamanpengamalan aktif dan pembelajaran yang berpusat pada siswa, sehingga siswa menemukan ide-ide mereka sendiri dan memperoleh makna oleh mereka sendiri (Nur, 2008). Melalui aktivitas pembelajaran yang berhubungan dengan fakta secara langsung maka akan mengubah persepsi siswa sehingga tidak terjadi miskonsepsi lagi.

Respon siswa rata-rata senang dan tertarik untuk mengikuti pelajaran dengan kondisi tersebut pada ketiga 
kelas replikasi rata-rata 94,1\%. Sekitar $83,7 \%$ siswa dari ketiga kelas replikasi menganggap baru terhadap komponen pembelajaran yang terdiri atas materi pelajaran, aktivitasaktivitas dalam kegiatan, lembar kerja yang tersedia, bentuk-bentuk evaluasi serta guru mengajar. Bahkan 97,3\% siswa dari ketiga kelas replikasi menganggap bahwa dengan aktivitas-aktivitas yang dilakukan dalam KBM sangat membantu dalam memahami konsep yang diharapkan dapat meminimalisir miskonsepsi siswa. Ketertarikan siswa terhadap pembelajaran akan memberikan kontribusi terhadap keberhasilan pembelajaran. Ketika siswa telah tertarik maka siswa akan memberikan perhatian yang lebih dan membuat mereka terlibat dalam pengalaman pembelajaran yang menyenangkan dan bermakna. Motivasi inilah yang membuat siswa melakukan aktivitas pembelajaran seperti yang teramati oleh pengamat, dengan intensitas yang cukup tinggi (Arends, 2012). Ketertarikan siswa terhadap pembelajaran juga ditunjukkan dengan 96,0\% siswa dari ketiga kelas replikasi setuju jika materi yang lain diajarkan cara yang sama.

Miskonsepsi siswa didiagnostik secara individu dan kelompok menggunakan analisis CRI (Hasan, 1999). Diagnostik miskonsepsi siswa secara individu digunakan untuk mengetahui persentase siswa yang mengalami miskonsepsi pada masing-masing konsep. Identifikasi miskonsepsi siswa secara berkelompok digunakan untuk mengetahui konsep yang paling banyak terjadi miskonsepsi. Konsep yang paling banyak siswa mengalami miskonsepsi sebelum pembelajaran dengan pendekatan CTL adalah konsep nomor 2 (asas Bernoulli), yaitu pada kelas replikasi I sebesar $61,0 \%$, sedangkan pada kelas replikasi II sebesar 52,0\%. Pada kelas replikasi I dan II jumlah miskonsepsi siswa yang paling banyak adalah pada konsep nomor 3 khususya pada soal no. 11 dengan CRIS masingmasing sebesar $4,13 \%$ dan 3,70\%, sedangkan pada kelas replikasi III mendapatkan fakta yang berbeda bahwa nilai CRIS yang terbesar pada konsep nomor 1 tepatnya pada soal nomor 2. Dengan hasil respon yang berbeda pada kelas replikasi III dibandingkan dengan kedua kelas replikasi, hal ini disebabkan penyebab miskonsepsi disetiap siswa berbeda. Penyebab terjadinya miskonsepsi menurut Suparno (2005) berasal dari siswa, buku, guru, konteks, dan cara mengajar. Pada penelitian ini lebih spesifik membahas penyebab miskonsepsi adalah berasal dari siswa terutama pada pemikiran asosiatif, pemikiran yang tidak lengkap, dan intuisi yang salah.

Menurut Berg (1991) prakonsepsi adalah konsepsikonsepsi awal yang dimilikki siswa mengenai konsepkonsep. Prakonsepsi ini dapat juga diartikan bahwa sebelum siswa mendapatkan pelajaran tertentu, siswa telah memilikki tafsiran-tafsiran awal. Pada penelitian ini yang dimaksud dengan prakonsepsi adalah konsepkonsep yang dimilikki oleh siswa sebelum pembelajaran dengan pendekatan CTL yang selanjutnya sebagai konsep awal siswa.

Pada hasil penelitian yang diperoleh dapat terbaca bahwa sebagian besar siswa mempunyai konsep awal yang salah. Menurut analisis CRI siswa pada konsep (1) (Persamaan kontinuitas) pada soal nomor 1 yaitu tentang ciri-ciri fluida ideal. Siswa mempunyai pemahaman bahwa jika air yang mengalir pada selang yang ujungnya ditekan akan mengalami perubahan volume (kompressibel). Pada soal nomor 2 yaitu tentang debit aliran air pada bendungan, jawaban siswa masih banyak yang mengalami kesalahan yaitu mereka mengatakan bahwa debit air pada tempat tersebut adalah berbeda. Pada soal nomor 3 yaitu tentang persamaan kontinuitas bahwa siswa mengalami miskonsepsi pada persamaan kontinuitas tersebut yaitu jarijari penampang pipa tanpa dikuadratkan mereka beranggapan menggunakan rumus A1.v1 = A2.v2 . Pada soal nomor 4 yaitu tentang laju aliran fluida, sebagian besar siswa tidak tahu konsep (rumus). Sedangkan soal nomor 5 yaitu siswa menjawab debit aliran fluida yang besar pada waktu yang sama diperoleh pada selang yang kecil.

Konsep (2) (asas Bernoulli) pada soal nomor 6 yaitu tentang ketinggian permukaan air pada pipa, siswa menjawab ketinggian permukaan air yang paling tinggi diperoleh pada selang yang dekat dengan pembuangan air. Pada soal nomor 7 yaitu pernyataan asas Bernoulli, bahwa siswa masih banyak yang menjawab tekanan yang besar itu terdapat pada tempat yang kecepatan aliran fluida yang besar pula. Pada soal nomor 8 siswa juga masih banyak yang mengalami miskonsepsi yaitu bahwa orang akan bergerak terdorong menjauh rel kereta api akibat dorongan angin dari kereta api tersebut. Sedangkan pada soal nomor 10 yaitu siswa banyak yang tidak tahu konsep (rumus) tentang perbedaan tekanan pada tempat yang memiliki kecepatan aliran fluida yang berbeda pula.

Konsep (3) penerapan asas Bernoulli (Teori Torricelli) pada soal nomor 11 yaitu siswa banyak mengalami miskonsepsi pada konsep ini karena siswa mengganggap bahwa pancaran air yang paling jauh adalah pada lubang yang paling bawah. Pada soal nomor 12 masih banyak yang menjawab salah karena siswa beranggapan bahwa air tidak akan terpancar lagi setelah $1 / 3$ air keluar sehingga tinggal 2/3 dari semula.

Konsep (4) penerapan asas Bernoulli (Pipa Venturimeter) pada soal nomor 13 yaitu siswa juga mengalami miskonsepsi bahwa tekanan air yang besar terdapat pada pipa yang kecil sehingga air akan mengisi pipa yang paling tinggi adalah pipa B. Sedangkan soal nomor 14 yaitu siswa beranggapan bahwa tekanan yang besar pada pipa yang luas penampangnya besar pula. 
Konsep (5) penerapan asas Bernoulli (gaya angkat sayap pesawat) pada soal nomor 9 yaitu siswa mengalami miskonsepsi juga, mereka menganggap bahwa ketika kertas ditiup bagian atas maka kertas akan bergerak kebawah karena adanya dorongan udara dari atas. Sedangkan pada soal nomor 15 yaitu siswa banyak yang menjawab benar tapi sebagian siswa masih memberikan alasan bahwa pesawat dapat terbang dikarenakan mesin pada pesawat terbang tersebut.

Kegiatan pembelajaran CTL pada tiap-tiap kelas replikasi dilakukan tiga kali pertemuan pada tiap-tiap pertemuan melaksanakan kegiatan yang sesuai dengan langkah-langkah kegiatan yang disusun didalam RPP. Setiap pertemuan melakukan kegiatan yang mencerminkan pembelajaran CTL yang meliputi kegiatan diantaranya; 1) kontruktivisme yaitu melaksanakan kegiatan yang selalu memotivasi siswa untuk mengkaitkan apa yang sedang dipelajari dengan pengetahuan/pengalaman sebelumnya dengan fenomena kehidupan sehari-hari sehingga siswa diharapkan dapat membangun pengetahuan dibenaknya sendiri, 2) inkuiri yaitu melakukan kegiatan pengamatan/ pecobaan yang dilakukan untuk menemukan kebenaran konsep sehingga tidak hanya sekedar menghafal rumus, 3) bertanya diharapkan dapat menggali rasa keingintahuan siswa terhadap sesuatu yang sedang dipelajari, 4) masyarakat belajar yaitu dengan membentuk kelompokkelompok belajar pada saat kegiatan eksperimen, 5) pemodelan yang dilakukan untuk memberikan contoh aktivitas yang akan dilaksanakan agar sesuai dengan prosedur pelaksanaan kegiatan, 6) melakukan refleksi yang bertujuan agar dapat mengetahui pemahaman yang dimiliki siswa setelah dilakukan pembelajaran, dan 7) penilaian autentik yang digunakan untuk mengetahui penguasaan konsep yang sudah dipelajari.

Untuk mengetahui keberhasilan pembelajaran CTL tersebut maka disetiap kegiatan dilaksanakan penilaian yaitu kognitif, psikomotor dan afektif. Penilaian kognitif yaitu dengan memberikan soal yang terdiri lembar penilaian kognitif 1 yaitu untuk mengetahui pemahaman konsep persamaan kontinuitas. Sedangkan lembar penilaian kognitif 2 yaitu untuk mengetahui pemahaman konsep asas Bernoulli beserta penerapannya. Hasil rata- rata penilaian kognitif yang diperoleh pada kelas replikasi I sebesar 80,2, kelas replikasi II sebesar 79,7, dan pada kelas replikasi III sebesar 80,7 .

Sedangakan penilaian psikomotor dilakukan pada tiga kali pertemuan yang diambil pada saat tiap pertemuan. Pertemuan pertama melakukan kegiatan ekperimen yang mengacu pada LKS 01. Pertemuan kedua melakukan kegiatan eksperimen yang mengacu pada LKS 03. Dan pertemuan ketiga melakukan kegiatan eksperimen yang mengacu pada LKS 04. Hasil rata-rata penilaian psikomotor pada ketiga pertemuan pada kelas replikasi I sebesar 81,1, kelas replikasi II sebesar 81.4, sedangkan kelas replikasi III sebesar 82,2. Begitu pula penilaian afektif dilakukan disetiap kegiatan pembelajaran yang mengiringi kegiatan eksperimen. Hasil rata-rata penilaian afektif yang diperoleh pada ketiga pertemuan pada tiap-tiap kelas replikasi adalah kelas replikasi I sebesar 82,2, kelas replikasi II sebesar 83,1, dan kelas replikasi III sebesar 82,8. Diperoleh kesimpulan bahwa pada kelas replikasi I tuntas secara klasikal sebesar 96\%, sedangkan pada kelas replikasi II dan III tuntas secara klasikal diperoleh sebesar 92\%. Hal ini menunjukkan bahwa pembelajaran melalui pendekatan Contextual Teaching and Learning menjadi efektif dan bermakna, dimana pembelajaran dapat mengukur kemampuan konsep siswa (Roihan, 2012).

Setelah siswa mengikuti pembelajaran dengan pendekatan CTL, mereka diidentifikasi kembali miskonsepsinya. Beberapa fakta yang disebutkan oleh Van den Berg (1991) bahwa 1) miskonsepsi sulit sekali diperbaiki; 2) seringkali "sisa" miskonsepsi terusmenerus mengganggu; 3) soal-soal sederhana dapat dikerjakan, tetapi dengan soal sedikit lebih sulit, miskonsepsi muncul lagi; 4) seringkali regresi, yaitu siswa yang sudah pernah mengatasi miskonsepsi beberapa bulan lagi salah lagi; 5) dengan ceramah yang bagus, miskonsepsi tak dapat dihilangkan atau dihindari;

6) siswa, mahasiswa, guru, dosen, maupun peneliti dapat terkena miskonsepsi; 7) siswa yang pandai dan lemah dua-duanya punya (potensi untuk miskonsepsi); 8) kebanyakan cara remediasi yang dicoba belum berhasil. Bertolak dari beberapa fakta ini, maka peneliti hanya sekedar berusaha untuk meremidiasi sehingga bermuara pada hasil penurunan jumlah miskonsepsi siswa.

Perubahan konsepsi yang awalnya tidak tahu konsep menjadi tahu konsep karena fenomena baru yang siswa peroleh dapat dengan baik dihubungkan dengan struktur pengertian yang sudah dimilikki oleh siswa. Perubahan konsepsi siswa yang awalnya miskonsepsi, setelah pembelajaran menjadi tahu konsep karena siswa mengubah konsepnya yang kurang sesuai dengan fenomena baru yang dihadapi. Bahkan semula siswa tidak paham konsep menjadi miskonsepsi sehingga jumlah miskonsepsi yang dialami siswa tidak berkurang melainkan meningkat. Perubahan konsepsi ini melalui proses rekonstruksi yang kuat, karena miskonsepsi sangat sulit diubah. Hal ini sesuai dengan yang diungkapkan Suparno (1999).

Pada penelitian ini perubahan konsepsi siswa tersebut yaitu dari tidak tahu konsep menjadi miskonsepsi, bahkan tahu konsep menjadi miskonsepsi setelah dilakukan analisis ditemukan bahwa siswa tidak jujur dalam menuliskan CRI, sehingga dalam penentuan 
siswa yang tidak tahu konsep, tahu konsep serta miskonsepsi tidak menunjuukan hasil yang sebenarnya, menurut Tayubi (2005) dalam penelitiannya menyatakan bahwa kejujuran siswa dalam mengisi CRI untuk menawab suatu soal sangat penting karena akan berdampak pada keakuratan hasil identifikasi yang dilakukan. Menurut Suparno (2005) bahwa beberapa perilaku siswa yang dapat mempengaruhi pemahaman konsep siswa diantaranya karena prakonsepsi, pemikiran asosiatif, pemikiran humanistik, reasoning yang tidak lengkap, intuisi yang salah, tahap perkembangan kognitif siswa, kemampuan siswa, minat belajar siswa. Untuk itu perlu ditekankan pada proses pengembangan konsep untuk membantu siswa belajar mulai dari konkrit ke abstrak serta menekankan pada penerapan-penerapan ke dunia nyata atau kehidupan sehari-hari yang autentik.

Miskonsepsi yang berasal dari siswa dapat diperbaiki melalui fakta autentik dari kegiatan praktikum atau demonstrasi (Suparno, 2005). Dengan kegiatan tersebut mampu menurunkan miskonsepsi. Hal ini dapat terlihat dari analisis penurunan miskonsepsi pada tiap- tiap kelas replikasi. Meskipun setelah pembelajaran dengan pendekatan CTL masih menyisakan miskonsepsi pada siswa di tiap-tiap kelas replikasi, tetapi nilai persentase miskonsepsi mengalami penurunan. Sehingga dapat dikatakan pembelajaran dengan pendekatan CTL cukup membantu siswa dalam proses penyembuhan miskonsepsi mereka, bahkan jumlah miskonsepsi siswa dapat diminimalisir.

Kendala-kendala yang ditemui selama kegiatan pembelajaran yang dilakukan selama penelitian, siswa mengalami kesulitan membuat hipotesis dari rumusan masalah yang sudah dirumuskan serta menentukan variabel-variabel pada kegiatan percobaan. Hal ini disebabkan dari hasil wawancara dengan siswa jarang melakukan kegiatan percobaan sehingga kesulitan dalam menentukan variabel-variabel percobaan. Kegiatan pembelajaran yang berlangsung diadakan pada jam pelajaran siang sehingga kondisi siswa sudah jenuh sehingga yang terjadi situasi yang ramai pada kegiatan pembelajaran khususnya pada saat siswa pada kelompok tertentu menampilkan hasil pengamatan/percobaan yang dilakukan. Dengan keterbatasan alat yang digunakan dalam kegiatan percobaan maka ini mengakibatkan dengan pembentukan kelompok yang anggotanya terlalu banyak yaitu satu kelompok 5 orang, hal ini menyebabkan ada siswa yang tidak mengikuti atau melakukan kegiatan percobaan dengan sunguh-sungguh. Dalam kegiatan percobaan pada materi fluida dinamis ini membahas tentang aliran fluida dalam hal ini adalah air. Pada saat membutuhkan air dengan aliran air yang cepat akan tetapi fasilitas aliran air pada kran yang ada disekolah tidak sesuai dengan harapan.

\section{KESIMPULAN DAN SARAN}

Berdasarkan hasil temuan penelitian, perangkat pembelajaran fisika melalui pendekatan CTL pada materi fluida dinamis yang telah dikembangkan dengan Model Kemp, diantaranya; 1) perangkat pembelajaran fisika pada materi fluida dinamis yang dikembangkan dalam penelitian ini meliputi; RPP, Buku Ajar Siswa, LKS, dan Soal Tes Diagnostik Miskonsepsi memiliki kualitas baik dengan sedikit revisi sehingga layak dan siap digunakan sebagai perangkat pembelajaran dalam proses kegiatan belajar mengajar, 2) keterlaksanaan pembelajaran fisika yang menggunakan perangkat pembelajaran dengan pendekatan CTL (Contextual Teaching and Learning) secara keseluruhan terlaksana sesuai dengan RPP yang telah dikembangkan dengan kategori baik. 3) aktivitas siswa selama penerapan pembelajaran fisika dengan pendekatan CTL (Contextual Teaching and Learning) mencerminkan bahwa sebagian besar aktivitas siswa yang sesuai dengan tahap-tahap pembelajaran. 4) Respon siswa selama proses pembelajaran dengan pendekatan CTL (Contextual Teaching and Learning) adalah baik, hal ini disebabkan siswa menganggap pendekatan yang digunakan merupakan hal yang menyenangkan bagi mereka, karena materi yang dipelajari dihubungkan/ dikaitkan dengan kehidupan nyata yang disertai dengan kegiatan praktikum sehingga belajar menjadi bermakna. Siswa setuju jika pembelajaran selanjutnya diberikan dengan cara yang sama, karena mereka menganggap dengan pendekatan CTL yang diterapkan pada pembelajaran mempermudah bagi mereka dalam menerima pelajaran sekaligus membantu memperbaiki miskonsepsi yang terjadi pada siswa. 5) Perangkat pembelajaran fisika dengan menggunakan pendekatan CTL mampu meminimalisir atau menurunkan miskonsepsi siswa pada sebagian besar materi fluida dinamis yang terdiri dari beberapa konsep yaitu persamaan kontinuitas, asas Bernoulli beserta penerapan asas Bernoulli, 6) hambatan yang ditemui dalam kegiatan pembelajaran fisika denagn pendekatan CTL antara lain terbatasnya alat serta fasilitas yang digunakan pada kegiatan percobaan, ukuran kelompok yang besar, suasana proses pembelajaran cenderung gaduh dikarenakan kegiatan proses belajar mengajar sebagian dilakukan diluar kelas. Selain itu, kemampuan siswa untuk membuat hipotesis dan mengidentifikasi variabel yang kurang menyebabkan guru harus banyak memberikan bimbingan.

Sehingga dapat disimpulkan bahwa,1) perangkat pembelajaran fisika melalui pendekatan CTL (Contextual Teaching and Learning) adalah layak digunakan. 2) Implementasi perangkat pembelajaran melalui pendekatan 
CTL (Contextual Teaching and Learning) mampu menurunkan atau meminimalisir jumlah miskonsepsi siswa pada materi fluida dinamis.

Berdasarkan simpulan yang telah diuraikan di atas, peneliti dapat memberikan beberapa saran sebagai berikut: 1) untuk mendukung proses pelaksanaan pembelajaran yang digunakan untuk menurunkan/ meminimalisir miskonsepsi siswa di sekolah tingkat SMA, pada mata pelajaran fisika terkait materi fluida dinamis, guru-guru dapat menggunakan perangkat yang telah dikembangkan ini, 2) bagi peneliti selanjutnya yang ingin mengkaji masalah miskonsepsi, dapat menggunakan perangkat dalam penelitian ini sebagai bahan pembanding atau pelengkap perangkat yang dikembangkan, 3) Persiapan dan pengelolaan waktu perlu diperhatikan, karena pembelajaran dengan pendekatan CTL membutuhkan waktu yang lama, 4) peneliti dan pengamat harus memiliki persepsi yang sama terhadap aspek yang akan diamati dan mendiskusikan hasil pengamatan untuk perbaikan pada pertemuan pembelajaran selanjutnya.

\section{DAFTAR PUSTAKA}

Arends, Ricard. 2012. Learning to Teach, Ninth Edition. New York: McGraw-Hill Companies, Inc.

Arikunto, S. 2005. Dasar-dasar Evaluasi Pendidikan Edisi Revisi. Jakarta: Bumi Rineka Cipta.

Berg, Euwe van den. 1991. Miskonsepsi Fisika dan Remidiasi. Salatiga: Universitas Kristen Satya Wacana.

Borich, G.D. 1994. Observation Skill for Effective Teaching. Second Edition. New York: McMillan Publishing Company.

Hasan, Saleem, D. Bagayoko, and E.L. Kelley, 1999. "Misconceptions and The Certainty of Response Index (CRI)". Phys. Educ. 34(5), pp. 294-299.

Ibrahim, M. 2012. Seri Pembelajaran Inovatif Konsep, Miskonsepsi dan Cara Pembelajarannya. Surabaya: Unesa University Press.

Johnson, E.B. 2002. Contextual Teaching and Learning: What it is and why it's here to stay. California: Corwin Press, Inc.

Nurdin, 2009. "Implementasi Pendekatan CTL (Contextual Teaching and Learning) Dalam Meningkatkan Hasil Belajar". Jurnal Administrasi Pendidikan Vol. IX No. 1 April 2009.

Ratnaya,I.G. 2006. "Implementasi Pendekatan Pembelajaran Kontekstual dalam Teknik Pemasangannya sebagai Upaya Perbaikan Kesalahan Konsepsi dan Peningkatan Hasil Belajar Mahasiswa Jurusan Teknik Elektro IKIP Negeri Singaraja”. Jurnal Pendidikan :dan Pengajaran UNDIKSHA, Edisi Khusus TH. XXXIX Desember 2006.
Suparno, Paul. 2005. Miskonsepsi dan Perubahan Konsep Pendidikan Fisika. Jakarta: PT. Grasindo

Suparno, Paul. 2006. Filsafat Konstruktivisme Dalam Pendidikan. Yogyakarta: Kanisius.

Tayubi, Y.R. 2005. “ Identifikasi Miskonsepsi Pada Konsep- Konsep Fisika Menggunakan Certainty of Response Index (CRI)". Jurnal Pendidikan Universitas Pendidikan Indonesia, No. 3/XXIV/2005.

Trianto. 2008. Mendesain Pembelajaran Kontekstual (Contextual Teaching and Learning) di Kelas. Jakarta: Cerdas Pustaka Publisher.

Wasis. 2006. "Contextual Teaching and Learning (CTL) dalam Pembelajaran Sains Fisika SMP”. Cakrawala Pendidikan, Februari, Th.XXV, No.1. 